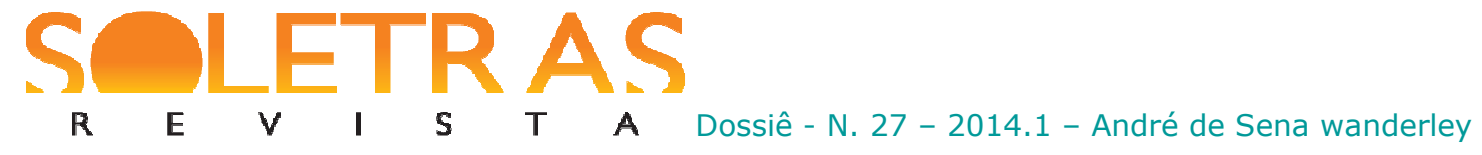

\title{
Os dois Teodoros: mutações do Gótico de Horace Walpole a E. T. A. Hoffmann
}

\author{
André de Sena Wanderley ${ }^{1}$ \\ Universidade Federal de Pernambuco
}

\begin{abstract}
Resumo: O presente artigo visa analisar, teórica e comparativamente, os aspectos imaginativos ligados ao universo noturno da prosa gótica, dos inícios, com $O$ castelo de Otranto (1764), de Horace Walpole (1717-1797), até a consolidação da novela noturna alemã (Nachtstück), através do cotejo daquela obra com o conto $O$ morgadio (1816), de E. T. A. Hoffmann (1776-1822). Busca-se, desse modo, compreender o início da verticalização autoconsciente do gênero horror, visto como uma das vertentes imaginativas da literatura romântica, de sua ânsia verossimilhante inicial até o surgimento de uma nova postura mimética (imaginativa), mais metalinguística e intertextual, que homenageia o Gótico inicial ao tempo que propõe novos aprofundamentos psicológicos. Compreende-se que o Gótico inicial ainda está ligado às imposições do métron e decoro classicistas, apesar dos textos teóricos iniciais (os prefácios) de $O$ castelo de Otranto se referencializarem nas obras do dramaturgo William Shakespeare para compor uma precursora possibilidade de binomia romântica (união do grotesco com o sublime), só efetivamente consubstanciada nas obras do Gótico tardio, como são exemplos vários contos de Hoffmann, que efetivam à perfeição a referida binomia, no óbvio incremento positivo e autoconsciente relativo à categoria do grotesco, em suas conexões com o horror. É graças a este incremento que há o aprofundamento das tipologias iniciais do Gótico e a abertura de espaço para todas as criações artísticas posteriores ligadas ao horror, incluindo as dos dias atuais.
\end{abstract}

Palavras-chave: Ficção gótica. Romantismo. Horace Walpole. E. T. A. Hoffmann.

As pioneiras experiências estéticas relativas ao Gótico literário, em sua vertente ligada ao horror, se embasaram exponencialmente nos motivos noturnos como contraproposta sui generis ao classicismo iluminista da segunda metade do século XVIII, este, grosso modo, defensor das regras de composição e decoro literários, de uma postura pragmática no plano científico e do mimetismo pautado em aspectos moralistas e propedêuticos.

Digo sui generis pelo fato de que, impondo-se aos poucos como fecundo e original veio ficcional - aparentemente em tudo contrário à Aufklärung -, o Gótico, em seus inícios,

\footnotetext{
${ }^{1}$ Professor Adjunto da Universidade Federal de Pernambuco (UFPE). Doutor em Letras pela UFPE, com estágio na Université Blaise Pascal de Clermont-Ferrand (França). Mestre em Letras (2002) pela UFPB e Graduação em Jornalismo (1999) pela UEPB. Tem experiência na área de Literatura Brasileira e Portuguesa, Literatura e Ensino, Teoria e Crítica Literárias, Poética, Literatura Comparada, especializando-se em Literatura oitocentista brasileira e europeia (Romantismo, Ultrarromantismo, Literatura fantástica, gótica, de horror, narrativas de viagem etc.). É o idealizador e líder do Belvidera - Núcleo de Estudos Oitocentistas, do Departamento de Letras da Universidade Federal de Pernambuco. Membro-pesquisador dos grupos de estudos "Vertentes do Fantástico" (UNESP-SP), "Núcleo de Estudos sobre Gêneros" (NIG-UFPE), “Associação de Estudos Portugueses Jordão Emerenciano" (UFPE), e autor/organizador de livros teóricos e literários.
} 


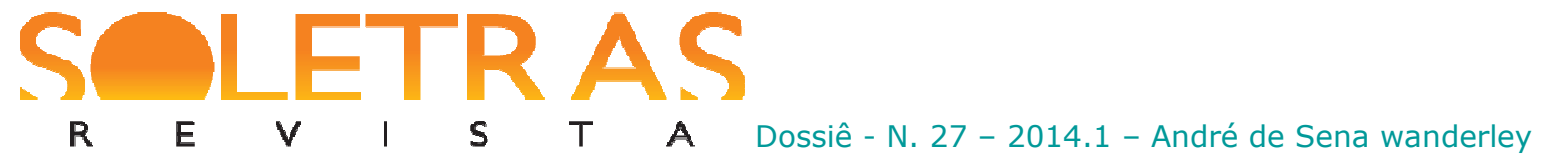

também endossou um tipo de mímesis própria que, se por um lado, ofereceu infinitas possibilidades imaginativas para ulteriores diegesis, por outro, continuou atento à necessidade de certo controle, de uma verossimilhança ainda cara aos artefatos ficcionais setecentistas como um todo.

Exemplo icônico disso é o livro O Castelo de Otranto (1764), de Horace Walpole (1717-1797), em cuja composição se fazem presentes tanto a verossimilhança de base mimética (Romantismo mimético) do romance histórico, como os elementos ligados ao horror sobrenatural ou de origem humana, atinentes a uma escrita imaginativa e não mimética (Romantismo imaginativo), além de sobrevivências classicistas.

No "Prefácio" à primeira edição do livro, Walpole, sob pseudônimo, opta por um procedimento que fará escola no Romantismo, quando, ficcionalmente, afirma ser a obra a publicação póstuma de um antigo manuscrito medieval, de origem italiana, que hipoteticamente estaria datado entre 1095 e 1243, épocas da primeira e última Cruzadas, respectivamente. A escolha de tal cronótopo não é aleatória, já que a ontologia medieval acataria os elementos sobrenaturais e maravilhosos:

\begin{abstract}
Os milagres, as visões, a necromancia, os sonhos e outras coisas sobrenaturais são hoje assunto explorado mesmo fora dos romances. No tempo em que o nosso autor escrevia, as coisas não eram assim; muito menos o seriam na época em que se supõe que a história tenha acontecido. A crença em toda a casta de prodígios estava tão enraizada nessas épocas obscuras que autor que não os referisse era infiel aos costumes do tempo. Não era obrigado a acreditar, mas tinha de representar os seus actores como crentes (WALPOLE, 1978, p. 18).
\end{abstract}

Ao situar sua história em tempos onde - acreditava-se - as experiências sobrenaturais seriam mais comuns, Walpole estaria realizando, de antemão, uma espécie de mea culpa, defendendo-se de uma escrita que não seria unicamente pautada pelo estro mimético? A pergunta é pertinente, pois, noutras passagens do mesmo "Prefácio", o autor revelará ânsias classicistas ao discutir o fim da obra e os caracteres de seus personagens, descritos à semelhança dos elementos que configurariam uma típica tragédia:

[...] Tudo tende para a catástrofe. A atenção do leitor nunca sofre afrouxamento. As regras do drama são sempre seguidas ao longo do desenrolar da peça. As personagens são desenhadas com mestria e segurança. O terror, que é o principal artifício do autor, evita que a história alguma vez decaia em vivacidade; tem na piedade um tal contraponto que a mente é obrigada a fixar-se constantemente na luta entre paixões tão adversas. Talvez algumas pessoas achem que as personagens dos criados são demasiado pouco sérias, se comparadas com o nível geral da história. Mais do que na oposição às personagens principais, o engenho do autor é bem visível no modo como pinta os subalternos. Há na história muitas passagens essenciais que, só pela naiveté e simplicidade deles, podiam ser trazidas à SOLETRAS, N. 27 (jan.-jun. 2014) ISSN: $2316-8838$

DOI: $10.12957 /$ soletras.2014.11273 
luz: mormente, no último capítulo, o terror tipicamente feminino e a fraqueza de Bianca, que, progressivamente, se ergue até ao auge da catástrofe. [...] [Não sou] tão cego que não veja os defeitos do autor que traduzo. Eu gostaria mais que ele tivesse baseado o seu plano numa moral mais útil que aquela em que se baseia: serem os pecados dos pais castigados na pessoa dos herdeiros, até à terceira e quarta geração [...] (WALPOLE, 1978, p. 19).

O excerto revela as preocupações usuais que norteavam a criação de obras artísticas naquele período (século XVIII). O olhar classicista e mimético está presente na configuração da catástrofe, na constatação da unidade de ação, no pedido de desculpas por se colocar numa mesma cena personagens nobres e plebeus, na necessidade de um escopo moral bem definido e até mesmo nomeado, para contrabalançar a hybris trágica. Por outro lado, a experiência do "terror" é nova, apesar de baseada, aparente e conceitualmente, nas exigências da imitatio pseudo-aristotélica típica do classicismo (lembremos ainda que o "terror" se conjuga, no excerto acima, à "piedade", como se prefigura na Poética aristotélica). Ao fim e ao cabo, a tutela conceitual servirá de apoio ao óbvio incremento do "terror" - em medidas discretas, amparadas no decoro, tão caro à irrupção da catarse nas tragédias clássicas - presente e preponderante em toda a tessitura d'O Castelo de Otranto, como fica evidente ao longo de sua leitura. Assim, baseando-se inicialmente em premissas classicistas, o Gótico assegurará novos construtos ficcionais, a reverberar um imaginário (noturno) até certo ponto inaugural (sem nos esquecermos do dionisíaco existente no aticismo) e a delinear seus próprios procedimentos inaugurais referentes ao universo da narrativa: estilísticos, cronotópicos, tipológicos, tópicos etc.

O incremento do "terror" nas diegesis góticas - assegurado, como dito, pela plena ocorrência do maravilhoso no cronótopo medievo - dará ensejo a todo um universo ligado à expressão do sobrenatural, ainda que modalizado pela perspectiva mimética do romance histórico. O sobrenatural, no Gótico inicial, cria fissuras num universo em que o "terror" já se encontra instalado, graças às atmosferas opressivas e noturnas nas quais deambulam os personagens. As atitudes hybristas do protagonista Manfredo, príncipe de Otranto, acusam ainda a tópica medieval do desconcerto do mundo, contudo, reconfigurada numa nova cravelha, que revela um novo horizonte de expectativas por parte do público setecentista, aparentemente ávido de brumas literárias.

O sucesso entre os leitores realmente demandará novas edições. No "Prefácio" à segunda edição d'O castelo de Otranto, publicada um ano depois, Walpole sai do anonimato e discute os conceitos de imaginação e verossimilhança, ao tratar do que chama de romance 


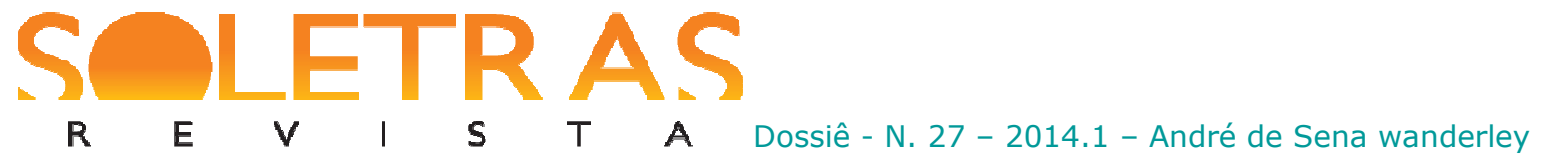

"antigo" (narrativas medievais e renascentistas) e "moderno" (setecentista), defendendo a união das características de ambos, para a geração do que hoje compreendemos como romance Gótico:

Grande cometimento é querer combinar dois gêneros de romance, o antigo e o moderno. Naquele tudo é imaginação e inverossímil; neste, há sempre a pretensão, por vezes conseguida, de copiar fielmente a natureza. Não há falta de imaginação; mas têm sido condenados os grandes recursos de fantasia, em favor de uma rigorosa obediência à vida quotidiana. A razão de nesta última espécie de romance a Natureza ser empecilho à imaginação, a razão está no facto de querer desforrar-se por, nos antigos romances, ter sido completamente posta de lado. Os actos, sentimentos e falas dos heróis e heroínas de antigamente eram tão pouco naturais como os mecanismos que os moviam. Achou o autor da presente obra que era possível reconciliar esses dois gêneros. Desejando deixar aos poderes da fantasia liberdade para se espraiarem pelos reinos ilimitados da invenção, criando a partir daí situações mais interessantes, houve o autor por bem descrever os mortais agentes do seu drama de acordo com as normas da verossimilhança, ou seja, pô-los a pensar, a falar e a agir como é suposto que devem agir todos os homens e mulheres que defrontam situações extraordinárias [...] (WALPOLE, 1978, p. 24).

Este segundo "Prefácio" é importantíssimo no que toca aos primeiros passos teóricos atinentes ao progressivo afastamento que o Romantismo autoconsciente ulterior proporá em relação ao real e à mímesis, para a gestação de enredos imaginativos. A mediania proposta por Walpole para o novo romance de sua época - consensual entre os aspectos sobrenaturais e verossímeis, norteada pela "invenção" e não mais pelo decoro - constitui um dos primeiros momentos afirmadores da "imaginação" romântica pela vertente inglesa, numa longa jornada da qual participará todo o continente literário europeu. O próprio Walpole antevê isso, quando afirma:

[...] Se esta nova estrada por ele [o autor d'O castelo de Otranto] aberta puder facilitar o caminho a homens de mais brilhantes talentos, o autor não deixará de reconhecer, com todo o gosto e modéstia, o facto de sempre também ter tido a consciência de que o seu esquema era passível de um embelezamento superior ao que a sua imaginação e a sua pintura das paixões lograram conseguir (WALPOLE, 1978, p. 24).

De mais a mais, uma vez que o romance conquistou sucesso entre os leitores, Walpole pôde obliterar, neste segundo "Prefácio", os aspectos ostensivamente classicistas do anterior, e assegurar, conceitualmente, os elementos imaginativos caros à série/estética/gênero/modo nascente (o Gótico e a própria literatura romântica). A presença de personagens plebeus, explicitada de forma negativa no primeiro "Prefácio", agora será percebida sob um novo prisma, também pioneiro no que toca aos estudos sobre a binomia romântica - a conjunção entre o sublime e o grotesco, Ariel e Caliban: 


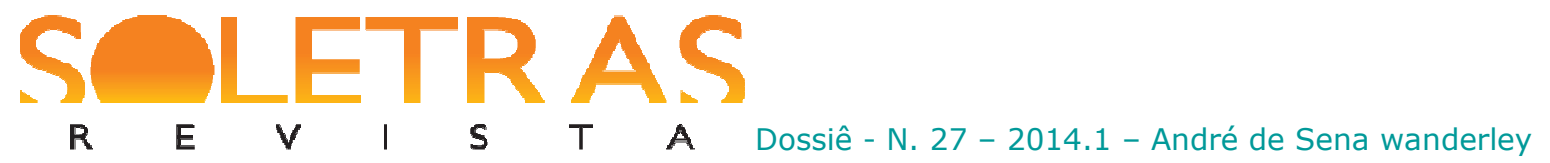

A respeito do comportamento dos criados, a que já me referi no prefácio anterior, seja-me permitido acrescentar mais umas palavras. A simpleza dos ditos criados, que quase tende para o ridículo e que a princípio parece em desacordo com a seriedade da obra, sempre se me afigurou, mais do que apropriada, muito adaptada ao fim em vista. A minha norma era ser natural. Embora sejam graves, importantes e merencórias, as sensações dos príncipes e dois heróis não apresentam, nos seus criados, cunho idêntico; pelo menos, estes últimos não exprimem nem podem exprimir as suas paixões com idêntica dignidade. Na minha humilde opinião, o contraste entre o sublime de uma coisa e a naiveté da outra coloca o carácter patético dos primeiros em maior evidência [...]. Mas, mais importante do que a minha opinião a esse respeito, é a desse grande mestre do natural, Shakespeare, cujo modelo eu copiei. Deixai que vos pergunte se as tragédias de Hamlet e de Júlio César não perderiam uma parte considerável do seu espírito e das suas maravilhosas belezas no caso de o humor dos coveiros, as tolices de Polônio e as facécias desajeitadas dos cidadãos romanos serem omitidas ou transformadas em falas heróicas? [...] (WALPOLE, 1978, pp. 24-25).

O conúbio entre o sublime e o grotesco é ensaiado por Walpole ainda no século XVIII, mais de 60 anos antes das teorias de Victor Hugo (1802-1885) sobre o mesmo tema, enfeixadas no prefácio à sua peça Cromwell (1827). A defesa walpoliana da binomia culmina num franco elogio a Shakespeare (que Hugo também repetirá) e em diversas críticas à obra ficcional e teórica de Voltaire - a antecipar também o Racine e Shakespeare (1825) de Stendhal (1783-1842) - ao longo de várias páginas, que reverberam uma postura anticlassicista e a defesa de um novo tipo de literatura, em que o real (diegético) não prescinde do grotesco e do sobrenatural.

Shakespeare substitui Aristóteles - ou a leitura ideologizada que o classicismo faz das teorias deste -, como patrono da nova literatura, no segundo "Prefácio". Por outro lado, não há cenas e passagens como esta, d'O Castelo de Otranto, no teatro do bardo de Stratfordupon-Avon:

[...] Crendo, pelo que podia observar, que estava perto da abertura da cripta, aproximou-se da porta que tinha visto entreaberta. Uma súbita corrente de ar vinda da dita porta apagou-lhe nesse momento a luz e ela ficou mergulhada na mais completa escuridão. Não há palavras que possam descrever o horror em que a princesa ficou. Sozinha em tão tenebroso local, com a mente povoada pelos terríveis acontecimentos [...] (WALPOLE, 1978, p. 47-48).

A cena da escuridão abrupta em que um personagem - estando ou não em fuga - se vê lançado, com óbvias associações sobrenaturais, ainda hoje é repercutida ao infinito pelo cinema de horror e tem sua origem na obra de Walpole. Neste caso específico, trata-se da personagem Isabella, perseguida ao longo dos corredores escuros e masmorras pelo príncipe Manfredo, após a morte do filho deste, Conrado, com quem aquela iria se casar. Ansioso por continuar sua linhagem e gerar um novo herdeiro, Manfredo passa a desprezar suas virtuosas 


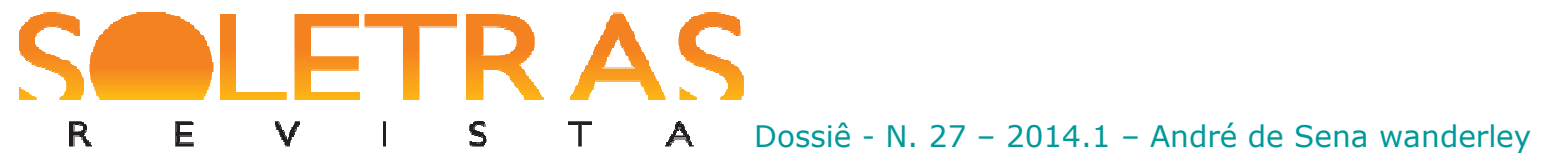

filha e esposa - esta última, por conta de não mais poder conceber - e de maneira insana tenta desposar Isabella, antes mesmo da realização dos funerais de Conrado. A atmosfera de pesadelo que ressumbra da narrativa é corroborada pelos motivos de ordem sobrenatural: Conrado morre esmagado pelo peso de um elmo gigante vindo não se sabe de onde e, durante a perseguição de Manfredo, um espectro gigante (provável origem do elmo) é visto pelas galerias do castelo, enquanto pinturas ganham vida e os seres nelas representados saem das molduras.

De fato, a escuridão, elemento onipresente, é o principal motivo - quase personagem - a endossar o estranhamento diegético e os elementos fantásticos d' $O$ castelo de Otranto. $\mathrm{O}$ protagonista Manfredo sempre se isola em seus aposentos e permanece em meio à escuridão, prescindido de lumes (p. 40); ele vê um espectro num aposento escuro (p. 44); os serviçais do castelo percorrem os corredores escuros do castelo temendo encontrar o espectro do finado príncipe Conrado (p. 55) etc. Por vezes, as réstias de luz que deixam entrever fenômenos surpreendentes também têm origem noturna, como naquela passagem em que Manfredo, no interior do castelo, observa o estranho elmo banhado pela cambiante luz da lua: "O luar que se erguia no céu e iluminava as janelas defronte mostrou a Manfredo as plumas do elmo fatal, que se erguiam à altura das janelas, balouçando ao vento tempestuoso e produzindo enorme zunido" (WALPOLE, 1978, p. 44). Num dos ápices da peripateia de horror, o nobre Frederico, pai de Isabella, indo ao oratório do castelo em busca da princesa Hippolita, para indagar-lhe a respeito de suas suspeitas referentes a Manfredo, dá de cara com um vulto ajoelhado em meio às sombras, e pensa tratar-se do padre confessor:

Não ficou o marquês surpreendido com o silêncio que reinava no aposento da princesa. De acordo com o que lhe tinham dito, julgou-a no oratório e para lá se encaminhou. A porta estava entreaberta e reinava lá dentro espessa treva. Empurrando a porta, lobrigou uma pessoa ajoelhada diante do altar. Aproximando-se, pareceu-lhe que não seria mulher, mas alguém que envergava hábito de burel e lhe virava as costas. Parecia estar absorto em oração. Ia o marquês retroceder quando o vulto, erguendo-se, se ficou por momentos em contemplação, sem para ele erguer o olhar. Enquanto esperava que a sacra personagem se aproximasse, o marquês, desculpando-se de tão indelicada interrupção, disse: - Reverendo Padre, procuro a princesa Hippolita. - Hippolita? - tornou-lhe uma voz cavernosa. - Viestes a este castelo à procura de Hippolita? E o vulto, voltando-se compassadamente, mostrou a Frederico o semblante descarnado e as órbitas vazias de um esqueleto, rebuçado na estamenha de um eremita (WALPOLE, 1978, p. 157158).

Os motivos religiosos são trabalhados de maneira disfórica em meio ao bizarro e ao fantasmagórico, contudo, ainda não se observa a realização de uma experiência ficcional de 


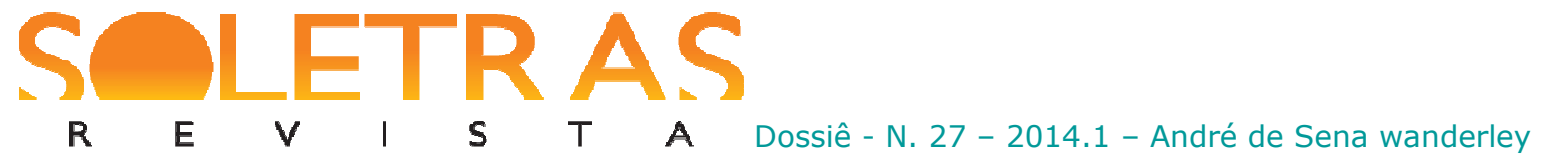

total inversão, ou mal absoluto, como as que obras ulteriores do Romantismo soerão realizar, a exemplo de Os elixires do diabo (1813; 1816), de E.T.A. Hoffmann (1776-1822). Ao término do excerto transcrito acima, descobre-se que o espectro aparentemente nefasto traduz alegoricamente o condão da virtude, e reencaminhará - como os típicos personagens eremíticos das novelas de cavalaria medievais - o marquês Frederico às sendas da virtude. $\mathrm{O}$ mesmo excerto também revela um procedimento icônico da escrita de horror, que tem em Horace Walpole um de seus criadores, a saber: o retardamento do clímax, gerador de suspense, tão utilizado pelo cinema de horror contemporâneo, muitas vezes, também conjugado ao silêncio e à escuridão.

Como afirmado, é em meio à escuridão que se passam os acontecimentos d'O castelo de Otranto, sobrenaturais ou não. É ela a real motivadora do estranhamento fantástico, da tensão diegética. Por sinal, os elementos efetivamente fantásticos ligados ao sobrenatural são, em geral, desmistificados ao longo da narrativa, a exemplo da aparição do espectro do gigante. Só os serviçais do castelo o veem e tal fato é associado às crendices populares - quando não, à bebida - na perspectiva dos nobres. Contudo, ao término da história, o gigante é visto - quase trágico deus ex-machina - por todos os personagens, nobres e plebeus, constituindo-se algo próximo do Fantástico-maravilhoso todoroviano, embora o signo do estranhamento típico do horror não se dilua.

O castelo de Otranto será base para uma série de outros romances e novelas góticas e sua influência se estenderá a todo o movimento romântico. Em O morgadio (1816), conto de E. T. A. Hoffmann, por exemplo, veremos como o imaginário noturno continuará servindo de base para novas experiências da literatura imaginativa, contudo, com características bem próprias. Na trama d'O morgadio também se observa a imagem do castelo perdido em meio ao locus horrendus:

Região selvagem e deserta. Alguns talos de erva conseguem, penosamente, furar o solo de areia movediça, aqui e ali. Em geral, um parque embeleza as cercanias da habitação senhorial, mas nessa se ergue miserável bosque de pinheiros, mais altos do que a muralha nua, de cor eternamente escura, parecendo desprezar a vestimenta da primavera. Nesse bosque, o pipilar contente dos pássaros é substituído pelo crocitar espantoso dos corvos e o silvar das gaivotas, cujo vôo prenuncia a tempestade (HOFFMANN, [19..], p. 97).

Trata-se do castelo do barão Roderich, lugar afastado e deserto só preenchido por outros nobres convivas durante as estrepitosas caçadas invernais, anunciadas pelos altissonantes clangores dos metais. Ao lado da esposa, a melancólica baronesa Serafina alma poética avessa a tais alaridos, nostálgica pela poesia e música delicadas que os membros SOLETRAS, N. 27 (jan.-jun. 2014) ISSN: 2316-8838

DOI: $10.12957 /$ soletras.2014.11273 


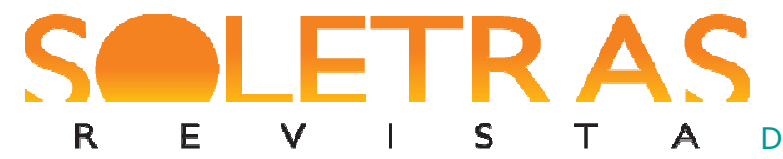

de sua casta desprezam -, Roderich é outro sisudo Manfredo, a contrabalançar o temperamento despótico com os prazeres que a caça proporciona. Mas o protagonista do conto é na verdade o personagem Theodor, jovem sobrinho de um velho juiz que anualmente se desloca ao castelo de Roderich para dar consecução às atividades burocráticas e judiciárias do povoado. Theodor, uma espécie de estagiário da área jurídica, escrevente, irá ao castelo pela primeira vez, onde se apaixonará pela baronesa Serafina desde a primeira troca de olhares, com quem compartilhará dos mesmos gostos poéticos e musicais (depois de muitas reviravoltas, Theodor e Serafina conseguirão realizar - longe dos olhos do barão Roderich alguns saraus musicais, com um piano trazido às ocultas do vilarejo, ao mesmo tempo que um amor secreto).

$O$ morgadio, apesar de todas as influências d' $O$ castelo de Otranto, já demonstra outra experiência relativa ao Gótico, ligada aos planos intertextuais e metalinguísticos, pari passu à completa assimilação da estética romântica. ${ }^{2}$ Walpole - talvez mesmo por injunções de ordem biográfica - respeita e reitera as convenções aristocráticas relativas aos personagens em sua obra, enquanto Hoffmann as despreza, valorizando o típico personagem descentrado romântico, cuja sensibilidade e talentos são mais importantes do que as castas e genealogias. N'O castelo de Otranto - apesar de toda importância, como afirmado, de seus prefácios para a gestação de uma noção de binomia romântica inglesa e da utilização do sobrenatural como processo imaginativo -, o único personagem efetivamente virtuoso tido como pertencente às camadas populares, o camponês Teodoro, ao final da diegese será inserido no universo da aristocracia, com a descoberta de que descenderia da alta nobreza italiana. As últimas barreiras que impediam o liame entre as ações virtuosas e o sangue aristocrático são eliminadas, numa postura conservadora e reacionária. Por sua vez, o Theodor do conto hoffmanniano é apenas um estudante de Direito e músico (pianista) - por sinal, como seu próprio autor, Ernest Theodor “Amadeus" Hoffmann, também advogado e virtuoso pianista, segundo o processo de espelhamento biográfico na ficção, tipicamente romântico -, contudo, capaz de gerar a féerie poética, os devaneios langorosos de onde promanam doses de erotismo sucinto e aquela melancolia inspiradora capaz de implodir as genealogias e outros ademanes nobiliárquicos. Personagem iconoclasta sem o desejar, incômodo por sua própria condição social e temperamento poético, Theodor é uma das grandes criações de Hoffmann, um

\footnotetext{
${ }^{2}$ Lambert (1979, p. 303) avulta os aspectos intertextuais e as citações/alusões a obras de Kleist, Schiller, Shakespeare, Jean-Paul Richter, Schnabel etc., presentes à narrativa de $O$ morgadio, os quais dão "um relevo especial" ao conto. Trata-se de um novo caminho ligado ao Gótico, ou seja, a busca por uma essência efetivamente literária e sem pretensões de associar a obra ficcional ao real empírico. 


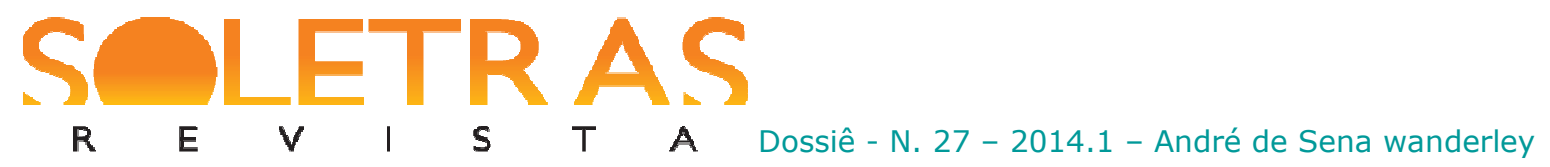

daqueles estudantes meio desastrados chamados a participar, como protagonistas, de alguma história excêntrica, semelhante ao que ocorre em muitas outras obras suas. Com este personagem, Hoffmann leva o Teodoro inicial walpoliano a um novo nível de maturidade ficcional, redimensionando-o num universo que é todo seu - e não mais o dos autores romântico-classicistas das primeiras gerações românticas europeias -, composto a um só tempo de atmosfera burguesa, de registros do universo das leis e da jurisprudência, bem como de boêmia, delírio e imaginação sem fronteiras que faz do horror um dos mais lúdicos exercícios ficcionais imaginativos do período oitocentista. $\mathrm{O}$ Theodor hoffmanniano possibilitará a metalinguagem do horror e a experiência fantástica do sobrenatural, pois, dotado de imaginação excêntrica, deixar-se-á impregnar em várias passagens não apenas pelas ambiências soturnas e inspiradoras do castelo, mas também da literatura:

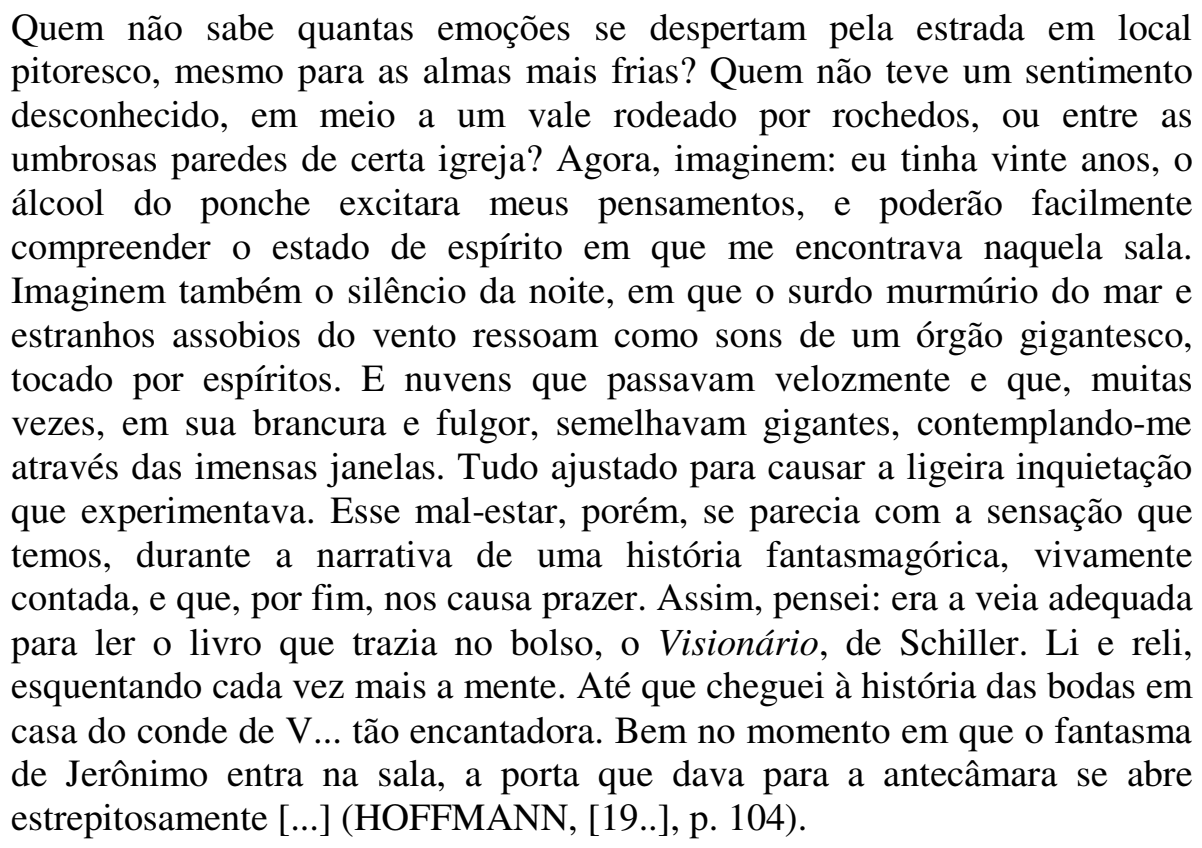

A partir da última frase, o personagem dá início ao relato das fantasmagorias testemunhadas naquele salão do castelo em que lia a obra schilleriana. A típica autossugestão romântica, em grande parte, haurida inicialmente das obras de J. J. Rousseau (1712-1778) e suas experiências ligadas ao devaneio é sugerida, neste momento específico, pelo ato de leitura do protagonista, no caso, de um livro de horror em meio à atmosfera sombria do castelo, sinergia entre a imaginação e o universo imanente muito cara ao romantismo alemão. O medo não é mais trabalhado como simples motivo episódico, a exemplo do que ocorre no Gótico walpoliano, mas autonomeado de forma metalinguística, também a gerar o mise en abyme (um leitor de histórias mal assombradas também é o personagem de outra a que lemos, estando ou não [nós, os leitores empíricos] em espaços desencadeadores de horror...), um 


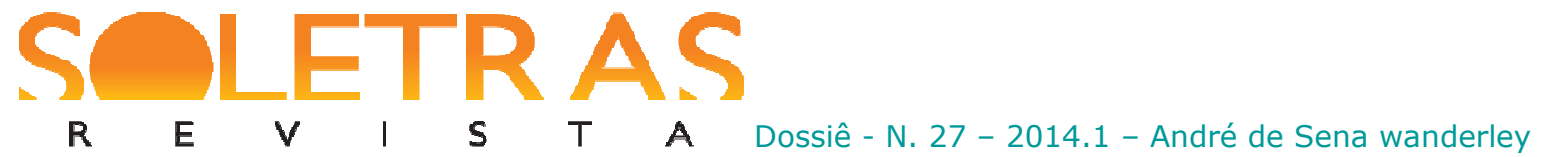

efeito literário que atesta a verticalização da estética inaugurada por Walpole, a qual ele próprio já havia entrevisto. $\mathrm{O}$ excerto iconiza as características da novela noturna alemã (Nachtstück), que, se também faz uso de todos os cronótopos ligados ao Gótico setecentista, por outro lado, trabalhará o horror numa dimensão mais psicológica e subjetiva. Segundo Volobuef (1999, pp. 67-68),

Para chegar a tanto [a passagem do Gótico tradicional à Nachtstücke], o modo por que era considerada a noite e outros motivos congêneres (escuridão, sombras, paisagem à luz da Lua etc.) foi sofrendo alterações [...]. A noite, portanto, foi transferida para dentro do indivíduo. Tal circunstância influiu diretamente na peça noturna romântica cuja propensão foi a de abandonar o tipo de motivo explorado pelo romance Gótico (castelos malassombrados, fantasmas vagando por corredores escuros, escadas sombrias, masmorras tenebrosas etc.) - os quais localizavam a origem do horror no ambiente fora do indivíduo -, para explorar o abismo soturno que o homem traz dentro de si, desfraldando todo um veio de motivos que concentraram o terror dentro do sujeito (tais como medo, solidão, loucura).

Acrescente-se a estas últimas características a imaginação desbordante de certos personagens românticos, a exemplo de Theodor, e teremos a experiência da fantasmagoria noturna mais típica da Nachtstück. De fato, muitas experiências sobrenaturais são atestadas pelo protagonista, ao tempo que revela seu temperamento poético: “[...] minha exaltação [dava] especial ímpeto às minhas palavras, talvez porque estivesse disposta [a baronesa Serafina] a me ouvir, ela se embevecia cada vez mais com as histórias fantásticas que eu inventava" (HOFFMANN, [19..], p. 109). Ora, com tais declarações, o leitor começa a desconfiar da referencialidade ligada ao sobrenatural na diegese; contudo, há cenas em que outros personagens também o experienciam, como aquela em que o tio de Theodor chega a esconjurar um suposto fantasma, gerando-se, muitas vezes, a ambiguidade fantástica. Ao término da narrativa, este último irá explicar os fatos históricos deflagradores do sobrenatural no castelo de Roderich numa analepse, mas não teremos ainda o "sobrenatural explicado" típico do gênero Estranho que Todorov (2007) associa ao Gótico setecentista (com a ulterior desmistificação dos fantasmas e fenômenos a eles ligados), devido ao fato de que Hoffmann continua possibilitando a presença do sobrenatural e do horror. O efeito estético do medo permanece ao fim da diegese, indo além do subgênero Fantástico-maravilhoso também asseverado por Torodov, característica da típica literatura de horror. Assim, os potenciais de estranhamento do texto são garantidos por um discurso elíptico e polissêmico que atesta a maioridade estética do Gótico, que prescindirá das marcações temporais (as datas de $O$ morgadio são construídas com reticências - [17...], e os fatos ocorridos não são possibilitados pela ontologia miraculosa medieval, mas aparentemente a de todas as épocas, pela via da 


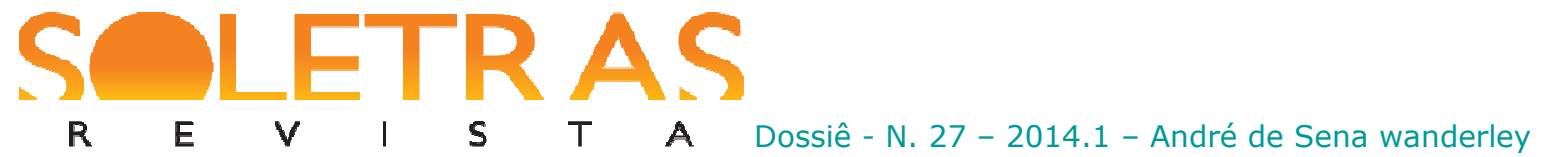

imaginação), da ânsia mimética e dos ideais conservadores ainda existentes na época de Walpole. É o indivíduo poético em contraste com a frieza e indiferença daqueles que perdem o contato com as forças criativas da natureza, que $O$ morgadio busca evidenciar em suas entrelinhas, pondo em suspensão os sistemas hierárquicos e a própria noção de real instituído, além dos procedimentos estritamente miméticos e verossimilhantes cultivados pelo romance histórico romântico tradicional.

Esta liberdade criativa e franco incremento imaginativo, que catapultam o surgimento de uma nova verossimilhança interna ou diegética e prescindem dos efeitos de real ansiados pelo romance histórico, não foram bem compreendidos por alguns teóricos da época. São famosas as críticas que o romancista histórico Walter Scott (1771-1832) tece em relação às liberdades hoffmannianas - estendidas a toda a literatura fantástica - especialmente quando o autor de $O$ vaso de ouro se aproxima deste gênero caro ao crítico (o romance histórico), a exemplo do que ocorre em $O$ morgadio. Scott inicia a crítica intitulada Sobre Hoffmann e as composições fantásticas com as seguintes palavras, que dão o tom geral de seu conteúdo:

O gosto dos alemães pelo misterioso levou-os a inventar um gênero de composição que talvez só pudesse existir no seu país e na sua língua. É aquele a que se poderia chamar o gênero FANTÁSTICO [sic], em que a imaginação se abandona a toda a irregularidade dos seus caprichos e a todas as combinações das cenas mais estranhas e mais burlescas (SCOTT, 1998, p. $\mathrm{XXI})$.

Em seguida, após se mostrar desgostoso pelo fato de Hoffmann não ter escrito uma obra realista e histórica a respeito das batalhas que havia presenciado na cidade de Dresden contra os exércitos napoleônicos, prossegue em sua crítica biografista, ressaltando o personagem do velho juiz de $O$ morgadio, tio de Theodor, como exemplo de fidelidade realista:

Há, principalmente, no conto intitulado $O$ Morgadio um personagem que é talvez peculiar à Alemanha e que forma um contraste notável com os indivíduos da mesma classe tal como estão representados nos romances e tal como, talvez, existem na realidade nos outros países. $O$ justiceiro B... exerce, na família do barão Roderic de R..., nobre proprietário de vastos domínios na Curlândia, quase o mesmo ofício que o famoso bailio Macwhecble exercia nas terras do barão de Bradwardine (se me for permitido citar Waverley) [...]. Tem as manias da velhice e um pouco de seu mau humor satírico; mas suas qualidades morais fazem dele, como diz com razão La Motte-Fouqué, um herói dos velhos tempos, que tomou o roupão e os chinelos de um velho procurador dos nossos dias. Seu mérito natural, sua independência, sua coragem são antes realçadas que empanadas por sua educação e sua profissão, que supõe um conhecimento exato do gênero humano [...] (SCOTT, 1998, p. XXII-XXIII).

Por outro lado - e de maneira inversa - o elogio a este personagem que mais se aproximaria da vida, logo se transmutará em uma séria crítica à obra como um todo, no SOLETRAS, N. 27 (jan.-jun. 2014) 


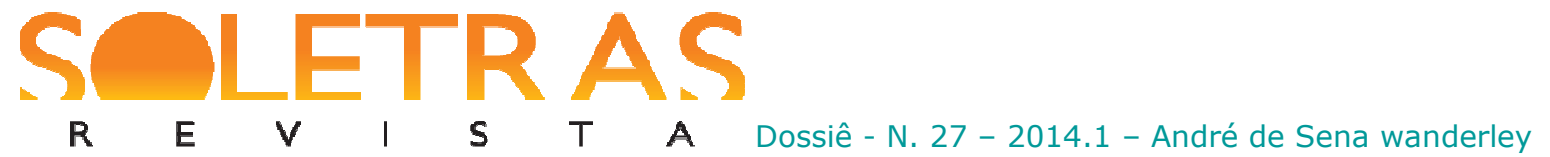

momento em que o autor escocês analisa outras características e personagens do conto hoffmanniano, sempre comparado às suas próprias produções de romance histórico e gótico tradicionais:

O conto que acabamos de citar mostra a imaginação desregrada de Hoffmann, mas prova também que ele possui um talento que deveria contêla e modificá-la. Infelizmente, seu gosto e seu temperamento o arrastam com demasiada força para o grotesco e o fantástico para lhe permitir retornar com frequência, em suas composições, ao gênero mais razoável no qual ele teria sido facilmente bem-sucedido [...]. Às vezes podemos deter nosso olhar com prazer num arabesco executado por um artista dotado de rica imaginação; mas é penoso ver o gênio se exaurir em objetos que o gosto reprova. Não gostaríamos de lhe permitir uma excursão nessas regiões fantásticas a não ser sob a condição de que ele trouxesse de lá ideias doces e agradáveis. Não poderíamos ter a mesma tolerância para com esses caprichos que não só nos espantam por sua extravagância como nos revoltam por seu horror (SCOTT, 1998, pp. XXIII-XXIV).

É interessante observar como o julgamento do tempo seguiu na contramão da imposição de mimetismo e verossimilhança por parte da crítica de Walter Scott às obras de Hoffmann. Sabe-se hoje que a "extravagância", o "horror", as "excursões" às "regiões fantásticas" se impuseram justamente como os grandes impulsos criativos renovadores do Romantismo. Além disso, cumpre lembrar que críticos posteriores, a exemplo do György Lukács, de $O$ romance histórico, revelaram como o romance histórico romântico - especialmente o scottiano - antecipam a estética realista, e se dissociam, em várias perspectivas, da própria série romântica. Sem demérito às obras ficcionais do romancista escocês, apenas não mais se compactuou de sua visão crítica que afirma a negatividade daquela "índole poética e metafísica levada ao excesso [...] sujeita à influência da imaginação" (SCOTT, 1998, p. XXV) que constitui, metalinguística e intertextualmente, a caracterização do novo Theodor o qual os novos tempos demandavam.

\section{Referências bibliográficas:}

HOFFMANN, E. T. A. O morgadio. In: HOFFMANN, E. T. A. O castelo mal-assombrado. Trad. Ary Quintella. São Paulo: Círculo do Livro, [19..], pp. 95-150.

LAMBERT, José. Notices et notes. In: HOFFMANN, E. T. A. Contes fantastiques I. Trad. Loève-Veimars. Paris: Garnier-Flammarion, 1979, pp. 301-314.

LUKÁCS, György. O romance histórico. Trad. Rubens Enderle. São Paulo: Boitempo Editorial, 2011.

SCOTT, Walter. Sobre Hoffmann e as composições fantásticas. In: HOFFMANN, E. T. A. $O$ pequeno Zacarias. Trad. Marion Fleischer. São Paulo: Martins Fontes, 1998, pp. XI-XXXI. 


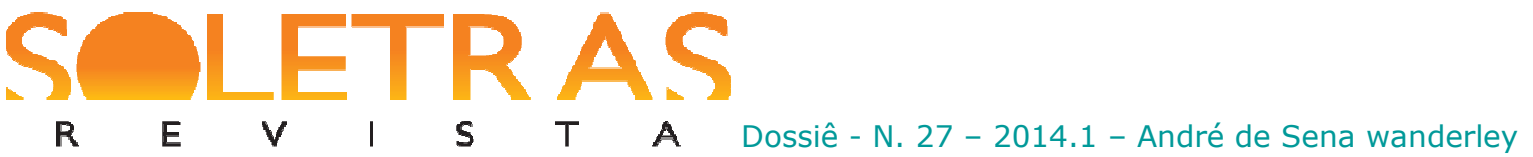

TODOROV, Tzvetan. Introdução à literatura fantástica. Trad. Maria Clara Correa Castello. 3. ed. São Paulo: Perspectiva, 2007.

VOLOBUEF, Karin. Frestas e arestas: a prosa de ficção do Romantismo na Alemanha e no Brasil. São Paulo: UNESP, 1999.

WALPOLE, Horace. O castelo de Otranto. Trad. Manuel João Gomes. Lisboa: Editorial Estampa, 1978.

\title{
The two Teodoros: mutations of the gothic from Horace Walpole to E. T. A. Hoffmann
}

\begin{abstract}
This article aims to analyze, theoretically and comparatively, imaginative aspects connected to the night universe of the Gothic prose, of the beginnings, with The Castle of Otranto (1764), Horace Walpole (1717-1797), until the consolidation of the night novel German (Nachtstück), through the comparison of that work with the tale The Morgadio (1816), from E. T. A. Hoffmann (1776-1822). The aim is to understand the beginning of the vertical self-conscious of the horror genre, seen as one of the imaginative aspects of the Romantic literature, of its mimetic eagerness and resemblance initial until the appearance of a frankly non-mimetic posture but intertextual and metalinguistic, that honors the initial gothic time proposing new psychological insights. It is understood that the original Gothic is still connected to the impositions of the measure and decorum classicists, despite the initial theoretical texts of The Castle of Otranto having as reference the works of the playwright William Shakespeare to compose a precursor possibility of romantic binomia (union of the grotesque with the sublime), only effectively consubstantiated in the works of the late gothic style, there are several examples of tales of Hoffmann, that actualize to the perfection of the binomia, in the obvious positive increment and self-conscious concerning to the category of the grotesque, in their connections with the horror. It is due to this increment that there is the deepening of the initial typologies of the Gothic and the opening of space for all future horror artistic creations, including those of the present days.
\end{abstract}

Key words: Gothic fiction. Romanticism. Horace Walpole. E. T. A. Hoffmann.

Recebido em: 15 de maio de 2014.

Aprovado em: 26 de agosto de 2014. 